This photograph was selected for comparison with those of $\mathrm{Mr}$. I'Anson because the rays are plainly shown, while the shadow of the mica sheet, which was between the coins and the photographic plate, can also be plainly seen. It will be noticed that the rays are most numerous between the coins.

Stanford University. Cal., February 19.

$$
\text { FERNANDO SANFORD. }
$$

[The photograph referred to by Mr. Sanford is similar to one which illustrated Mr. I'Anson's letter (p. 270), the chief difference being that a greater number of rays are shown in the space separating the two coins.-En. NATURE.]

\section{Laboratory Use of Acetylene.}

IN your issue of September 3, I896, appeared a short letter stating that acetylene was in use in our laboratory for blowpipe work, and further stating that we hoped to introduce the gas on to the benches. From one or two inquiries received since then, it would seem that the fact of our now having succeeded in doing this will be of interest, as, indeed, it should be to any one possessing or contemplating the erection of a laboratory in the country where ordinary gas is costly or not obtainable. We use an ordinary Bunsen of special dimensions, the aperture of the jet being very small, and the tube (also of small diameter) is provided with a cap to protect the burner from dust when not in use. The generator is a modified form of one of those at present in the market, and gives between seven and eight inches wate pressure. With six inches pressure a perfectly non-sooty flame of crood size can be obtained, and a "quarter Bunsen flame" under as little as three and a half inches. If turned lower than this, the flame becomes luminous, the draught becoming insufficient. The flame is steady, noiseless, and, unless turned too low, evinces no tendency to strike down. The consumption of gas averages one cubic foot per burner per hour. The flame possesses, of course, great heating power, one volume of acetylene being for practical purposes nearly twice as effective as one volume of ordinary gas. This means an immense saving of time in all heating operations, and in many cases, such as small fusions and simple glass-working operations, we are able altogether to dispense with the blow-pipe; the burner alone supplying quite sufficient heat. Our installation has only just come into use, but, so far, has given us no trouble. We have used an acetylene blow-pipe for nearly a year, and have had no difficulties. The cocks and general fittings should be thoroughly good; any one who has not gone into the matter will be surprised to find what an indifferent article, as regards leakage, is the average gas-cock. It will be found that the cocks tend to work stiff, probably on account of the absorption of the acetylene by the lubricant, and it is much to be desired that the question of the most suitable lubricant should be investigated.

The Laboratory, Felsted School, Essex. A. E. Munby.

\section{Immunity from Snake-bites.}

Is case any of your readers may be working on the subject suggested by Mr. Dawson Williams in NATURE, March 4, page 415 , that mosquitoes may be the carriers of pathogenic microbes, I send you the following.

In a town in the interior of Asia Minor, where I resided some years, and where malarial fever was at all times very common, I frequently noticed that when the wind blew from the direction of swamps in the vicinity, bringing numbers of mosquitoes, there would be an increase in the number of men, both native and European, down with fever about a week later. Had the wind brought the malaria, or dust containing fever germs from the swamps, the increase in number of fever cases might have been expected within two or three days; but as generally a week elapsed, some less direct cause was to be sought, and I always thought the mosquitoes were the culprits.

That mosquitoes do more than inject a specific toxin may be inferred from a fact I have noticed-that people who have been living in the interior of this country and have become inured to the bites of the insects from the swanips, on coming to this town, where sewerage and dirt of all descriptions abound, are painfully conscious of the attacks of mosquitoes here, nd vice v'ersî.

Those who have suffered much from fever are generally immune from the usual pain of mosquito bites, and I have heard natives say that they have suffered so much from fever that even the mosquitoes will not bite them.

During the summer months, in certain localities in the interior, labourers are exposed to the bites and stings of tarantulas and scorpions. I have frequently seen men stung several times in the same season, and found that invariably they suffered less from each successive sting or bite.

Smyrna, March I2.

\section{The Stereoscopic Studies of Clouds.}

SINCE I 894, I have been making stereoscopic studies of clouds with wide separation of the cameras.

Beyond the direct interest of the pictures, the method has a practical value.

(I) In the measure of the distance of clouds by photogrammeters, it is usual to mark by a pin-prick the corresponding points of the two prints. Through the vagueness of cloud outlines it is easy to err in doing this, but any error thus made is easily detected by the stereoscope.

I have recently learnt that this method has been already suggested by Mr. M. J. Amsler-Laffon, of Schaffhausen, but I do not know whether it has been previously put to a practical test.

(2) My photographs were taken by visible signal without electric connection, some of them with a base of fully five hundred yards, and the clear stereoscopic definition seems to show that in ordinary cases the expensive electric connection of the cameras may be dispensed with, without affecting the value of the plates for purposes of measurement.

I9 The Boltons, S.W.

John TenNant.

\section{FAMOUS SCIENTIFIC WORKSHOPS.}

\section{I.-LORD KelviN'S LABORATORY IN THE UNIVERSITY OF GLASGOW.}

$\mathrm{A}^{\mathrm{S}}$ Lord Kelvin stated nearly twelve years ago, in an $A$ address at the opening of the Physical and Chemical Laboratories at the University College of North Wales, the establishment of scientific laboratories at universities and colleges for the experimental training of students is a comparatively recent idea. Private laboratories, no doubt, existed at a very early period. The old alchemists had places, sometimes secret retreats, meanly appointed, like the den of Wayland Smith, sometimes, when the purse and protection of a powerful patron were at their command, more luxurious quarters, in which they carried on their search for the elixir of life, and the key to the transmutation of metals.

Der in Gesellschaft von Adepten,

Sich in die schwarze Küche schloss,

Und, nach unendlichen Recepten,

Das Widrige zusammengoss.

When what was spurious and unscientific in the old alchemy had gradually sublimed away, when chemistry had grown up in its place, and the experimental study of natural philosophy had begun, the only laboratories (anatomical schools excepted), as a rule, were those in the houses of investigators, and to these admission was given by the masters only to their favourite disciples. There the work done was entirely that of research : such a thing as a course of laboratory exercises, carried on with a view to the passing of an examinational test of experimental knowledge and dexterity, was undreamed of. What a change has taken place! Now, no scheme of instruction in physics, chemistry, or biology is deemed complete which does not include an extensive course of practical work to be performed by the ordinary students; and excellent and well-appointed laboratories are provided at every institution which aims at giving university instruction in scientific subjects. This is all as it should be, were it not that the examinational test is in too many cases made a great deal too much of.

The Scottish Universities have often been criticised adversely, most frequently by men who knew little about

NO. I 43O, VOL. 55] 